\title{
PHYSIOLOGICAL RESPONSES AND LACTATIONAL PERFORMANCE OF FARAFRA AND SAIDI SHEEP AS AFFECTED BY SUPPLEMENTATION OF PROBIOTIC WITH NATURAL ANTIOXIDANTS
}

\author{
A.A.K. Saleh and A.A.A.I. Gomaa \\ Sheep and Goats Dept., Animal Production Research Institute, Giza, Egypt.
}

(Received 4 /10 / 2016, Accepted 22 /11 / 2016)

\section{SUMMARY}

$\mathrm{A}$ total of 88 ewes were used in this study in two trails (44 per each trail) to investigate the effects of supplementation of probiotic abbreviated as (Effective Microorganisms with Medicinal Herbs-EMMH) on physiological responses during thermonuteral and heat stress conditions and milk yield of two local breeds (Farafra and Saidi). The studied probiotic consisted of mixed culture of two strains of fungi (Trichoderma reesei and Aspergillus oryzae) with dry live baker's yeast (Saccharomyces cervisiae) and the mixed culture was enriched with natural antioxidants of herbal medicine plants. In the first trail, 22 Farafra and 22 Saidi ewes were used during summer, along mating and pregnancy seasons until parturition. In the second trail, 22 Farafra and 22 Saidi ewes in late pregnancy were used. Ewes of every breed were divided homogonously into two equal groups (11 ewes per each). Group (I) fed basal diet (concentrate feed mixture + rice straw). Group (II) fed basal diet $+3 \mathrm{~kg}$ EMMH/ton. Reproductive traits were estrus duration, conception rate (\%) and gestational period, number of lambs born, number of twins and birth weight was recorded. Thermal responses, gas exchange parameters and heat production measurement were determined during thermoneutral (comfort) conditions and during heat stress condition (after exposing animals to direct sun for 2 hours). Also, climatological data were recorded periodically. Daily and total milk yield were measured along the lactation season using lambs sucking technique. Body weight gain of suckling lambs, weaning weight and survival rate were recorded. Also, values of heamatocrit \% (Ht), total protein (TP) sodium (Na), Potassium (K) and total antioxidant capacity (TAC) were determined in ewes. In thermonuteral conditions, EMMH supplemented group had significantly $(\mathrm{P}<0.05)$ lower rectal temperature than control group in Farafra ewes. Whereas, in heat stress conditions, rectal and skin temperature significantly $(\mathrm{P}<0.05)$ decreased in EMMH supplemented group in both breeds. Respiration rate was significantly $(\mathrm{P}<0.05)$ lower in supplemented group than control in Farafra ewes only. Tidal volume was significantly $(\mathrm{P}<0.05)$ higher in EMMH group. While, metabolic rate and heat production values were significantly $(\mathrm{P}<0.05)$ decreased in EMMH supplemented group. Average body weight and body weight change of ewes significantly $(\mathrm{P}<0.05)$ improved by EMMH supplementation. Conception rate was improved in EMMH group compared to control in both breeds $(90.9 \%$ vs. $72.7 \%$ in Farafra ewes) and (81.8 vs. $72.7 \%$ in Saidi ewes). Furthermore, average litter size per ewe, number of lambs born per group, number of twins born per group were improved by EMMH supplementation. Total milk yield, average daily milk yield per ewe, weaning weight and total gain of lambs were significantly $(\mathrm{P}<0.05)$ improved by EMMH supplementation in both breeds. Also, survival rate was improved in EMMH group in both breeds. Values of total protein concentration (TP) and total antioxidant capacity (TAC) was significantly $(\mathrm{P}<0.05)$ higher in EMMH supplemented group in both Farafra and Saidi. From the present results, it can be concluded that supplementation of EMMH probiotic had a favorable effect in improving physiological responses of animals during heat stress and can ameliorate the adverse effects of heat stress. Also, it led to improve lactational performance of ewes and the performance of their suckling lambs.

Keywords: Physiological responses; probiotic; antioxidants; heat stress.

\section{INTRODUCTION}

Nowadays, there is a growing need for developing new supplements or feed additives and techniques that can improve animal performance and to some extent alleviate the adverse effects of some environmental factors such as heat stress which is one of the most important factors affecting adversely animal productivity in our countries. From these supplements which were widely used to improve animal performance are groups of antimicrobial growth promoters, probiotics, vitamins, minerals, enzymes, amino acids ....etc. But, it is important to note that some of these supplements beside its favorable effect on animal performance had a 
harmful side effects on human health. Recently, there is a global trend in animal feed sector strongly suggest using natural sources of feed additives such as herbs and medical plants which known to contain photogenic compounds that have antibacterial, antifungal, antiviral and antioxidant properties which could enhance animal health and productivity without harmful effects on human health or the environment (Wolter, 1995).

Probiotic is a term that means "For Life" and defined as live microorganisms which affected beneficially the host's health by improving microbial balance, stimulate growth and as well as modifying the intestine ecology and flora (Burgain et al., 2011). Furthermore, probiotics can provide many of health benefits which include competition, antagonistic effects, enhancement of digestion, strengthening of the immune system and stimulation of vitamin production (de Baets et al., 2009).

Probiotics and yeast cultures are rich source of vitamins, enzymes and other important nutrients. El-Shaer (2003) reported that all nutrients digestibility and nitrogen balance were improved by supplementation of yeast culture and probiotics in sheep. Probiotics exhibit antioxidant activity in such ways including that they may reinforce the inherent cellular antioxidant defense by secreting enzymes like superoxide dismutase and also, they release and promote the production of the major non-enzymatic antioxidant and free radical scavenger glutathione, (Abd El-Moneim et al., 2012). In addition, they promote the production of certain antioxidant biomolecules, such as the exopolysaccharides. All these data suggest that probiotics may have a potential therapeutic role in reactive oxygen species, characterized gastrointestinal disorders (Spyropoulos et al., 2011). Also, it was reported that antioxidants supplementation protect the body defense system against excessively produced free radicals during heat stress and stabilize health status of the animal (Sivakumar et al., 2010).

We aimed in this study to investigate the effects of supplementation with a locally manufactured probiotic abbreviated as (Effective Microorganisms with Medicinal Herbs-EMMH) on physiological responses during thermonuteral and heat stress conditions and lactational performance of two local breeds (Farafra and Saidi).

\section{MATERIALS AND METHODS}

This study was carried out in Mallawi Animal Production Research Station (Minia Governorate) belongs to Agriculture Research Center, Cairo, Egypt. The longitudes of Mallawi was (27.72 $\mathrm{N}^{\circ}$ ), Latitudes was $\left(30.83 \mathrm{E}^{\circ}\right)$ and its distance from Cairo is $300 \mathrm{Km}$. This study included two experiments as follow:

The first trial: This trial was conducted during the period from May to October 2013 (6 months) along mating and pregnancy seasons until parturition. A total of 44 ewes (22 Farafra and 22 Saidi) aged 2.0-4.0 years and with average body weight of $34.9 \pm 1.5 \mathrm{~kg}$ for Farafra ewes and $32.8 \pm 1.4$ for Saidi ewes were used in this experiment.

The second trial: This trial was carried out during the same period in 2014. This experiment was conducted on late pregnant ewes, began one month before parturition and continued along lactation till weaning of lambs. This experiment included 44 ewes (22 Farafra and 22 Saidi) aged 2.5-4.0 years and with average body weight of $43.1 \pm 1.2 \mathrm{~kg}$ for Farafra ewes and of $42.7 \pm 1.1$ for Saidi ewes.

All animals were carefully chosen as healthy and homogenized and were fed in groups according to $N R C$ (1985). Chemical composition of feed stuffs is shown in Table (1).

Table (1): Chemical composition of feed stuffs.

\begin{tabular}{lccccccc}
\hline \multirow{2}{*}{ Item } & \multirow{2}{*}{ Moisture } & \multicolumn{6}{c}{ Dry matter composition (\%) } \\
\cline { 3 - 8 } & & OM & CP & CF & EE & NFE & Ash \\
\hline Concentrate feed mixture (CFM) & 9.3 & 92.7 & 14.6 & 15.1 & 4.9 & 58.1 & 7.3 \\
Rice straw & 9.1 & 84.1 & 4.0 & 33.4 & 1.6 & 45.1 & 15.9 \\
\hline
\end{tabular}




\section{Experimental design:}

Animals of every breed were divided into two equal groups (11 ewes each) as follow:

Group (I): Control fed basal diet (concentrate feed mixture + rice straw).

Group (II): fed basal diet + $3 \mathrm{~kg}$ EMMH/ton.

EMMH is the abbreviation of (Effective Microorganisms with Medicinal Herbs), which is a co-culture probiotic consisted of two strains of fungi (Trichoderma reesei and Aspergillus oryzae) with dry live baker's yeast (Saccharomyces cervisiae) and the mixed culture was fortified with natural antioxidants of herbal medicine plants. The media is enriched with medicine herbal mixture providing $0.5 \mathrm{mmol}$ of antioxidants per gram of the final product. The product analysis was as follow: Moisture (12-15\%), organic matter (70-72\%), total nitrogen (3.2-3.4\%), organic carbon (40-41\%), true protein nitrogen (2.2-2.4\%). EMMH is biochemically contains some important enzymes like ( $\alpha$-Amylase, Cellulase, Xylanase, Poly galactrunase, Pectinase and Protease) and the live yeast count was $7500000 \mathrm{cell} / \mathrm{g}$. The supplementation level of EMMH used in this study was according to a previous study by (El-Badawi and Abedo, 2009) who recommended that suitable levels of EMMH supplementation were 0.1, 0.2 and $0.3 \%$.

Animals were fed in the first month of the experiment on the experimented diets as acclimation period.

\section{Measurements and procedures}

\section{The first trial}

\section{Thermal responses and respiratory activities}

Thermal responses in terms of rectal, skin and wool temperatures were recorded and respiratory activities in terms of respiration rate and gas volume/minute were measured by Dry Gas Meters. Tidal volume was calculated, $\mathrm{O}_{2}$ consumption and $\mathrm{CO}_{2}$ release were measured by oxygen analyzer (Servomex 570) and then heat production (HP) and metabolic rate (MR) were calculated. All of these parameters were taken in thermonuteral conditions (before solar exposure "BSE" at $9.00 \mathrm{am}$ ) and were taken also at heat stress conditions (after 2 hours of exposing animals to direct sun "ASE"). All animals were exposed daily during the study period to direct solar radiation for 2 hours from 12:00 am to 2:00 pm. Ambient temperature and relative humidity were recorded and temperature humidity index (THI) was calculated according to Hahn et al., (2003). Climatological data during studied period are presented in Table (2).

$\mathrm{THI}=[(\mathrm{TDB} \times 1.8)+32]-[(0.55 \mathrm{X}(\mathrm{RH} / 100) \mathrm{X}(\mathrm{TDB} \times 1.8)+32]-58$.

Where: $\mathrm{TDB}=$ Dry bulb temperature in ${ }^{\circ} \mathrm{C} . \quad \mathrm{RH}=$ Relative humidity, $\%$.

Table (2): Climatological data during the experimental period.

\begin{tabular}{lcccccc}
\hline \multirow{2}{*}{ Months } & \multicolumn{2}{c}{ Ambient temperature $\left({ }^{\circ} \mathrm{C}\right)$} & \multicolumn{2}{c}{ Relative humidity $(\%)$} & \multicolumn{2}{c}{ Temperature humidity index (THI) } \\
\cline { 2 - 7 } & BSE & ASE & BSE & ASE & BSE & ASE \\
\hline June & $32.6 \pm 0.6$ & $34.7 \pm 0.5$ & $43.6 \pm 0.4$ & $41.6 \pm 0.75$ & $82.8 \pm 1.3$ & $86.1 \pm 1.2$ \\
July & $33.9 \pm 0.7$ & $36.2 \pm 0.6$ & $47.1 \pm 0.6$ & $42.3 \pm 1.02$ & $83.9 \pm 1.1$ & $87.2 \pm 2.4$ \\
August & $40.7 \pm 0.8$ & $41.3 \pm 0.5$ & $21.6 \pm 0.3$ & $16.5 \pm 0.71$ & $99.7 \pm 2.8$ & $101.9 \pm 2.2$ \\
September & $31.7 \pm 0.9$ & $34.1 \pm 0.8$ & $51.2 \pm 0.6$ & $43.2 \pm 1.1$ & $80.3 \pm 1.4$ & $85.1 \pm 1.9$ \\
Overall mean & $34.6 \pm 0.7$ & $36.5 \pm 0.51$ & $40.8 \pm 0.43$ & $35.9 \pm 0.81$ & $86.7 \pm 1.7$ & $90.61 \pm 1.9$ \\
\hline \multicolumn{5}{c}{ ASE $=$ After sun exposure } \\
\multicolumn{7}{c}{ Before sun exposure }
\end{tabular}

\section{Reproductive traits}

In this part, ewes were estrus detected by a teaser ram three times daily for 35 days and fertile rams were used to breed ewes that showed estrus. Ewes exhibited estrus were bred twice, at the beginning of estrus and later after $12 \mathrm{hrs}$. Estrus duration (hrs) was recorded and conception rate (\%) was determined according to the 
number of diagnosed pregnant ewes by Sonar at 45 days after mating. Gestational period was calculated. Also, number of lambs born/ewe and birth weight recorded.

\section{The second trial}

\section{Milk yield of ewes and some traits related to their lambs}

Milk yield was recorded weekly for each ewe from the fifth day post-lambing till the end of lactation season (75 days) and weaning of lambs. Daily milk yield was measured using lambs suckling technique as it was reported by Ashmawy (1980). Birth weight of lambs was recorded after parturition, body weight gain of suckling lambs, weaning weight and survival rate \% were recorded at weaning.

\section{Blood sampling and measurements}

Blood samples $(6 \mathrm{ml})$ were collected from each animal via the jugular vein at morning before feeding and drinking. This sample was divided into two parts. The first part was taken in a tube with anticoagulant for measuring hematocrit $(\mathrm{Ht})$ by haematocrit capillary tubes centrifuged at 3000 r.p.m. for 15 minutes. The second part was taken in a tube without anticoagulant and centrifuged for separating serum which was freezed until the analyses of blood metabolites. Total protein, sodium, potassium and total antioxidant capacity were determined using commercial kits by colorimetric method.

\section{Statistical analysis:}

Statistical analysis was carried out using SPSS 17.0 for Windows (SPSS, 2010). Data was analyzed by General Leaner Model (GLM) procedure. The following model was used:

$$
\begin{aligned}
& Y_{i j k l}=\mu+T_{i}+B_{j}+(T B)_{i j}+E_{i j k} \\
& Y_{i j k l}=\text { The studied trait. } \\
& \mu=\text { The overall mean. } \\
& T_{i}=\text { The effect of treatment } \mathrm{i}=(\mathrm{C}, \text { EMMH }) . \\
& B_{j}=\text { The breed effect, } \mathrm{j}=(\text { Saidi, Farafra }) . \\
& (T B)_{i j}=\text { The effect of interaction between treatment and breed. } \\
& E_{i j \mathrm{jl} l}=\text { The experimental error. }
\end{aligned}
$$

\section{RESULTS AND DISCUSSION}

\section{The first trail:}

Thermal responses, respiratory activities and heat production measurements of ewes during thermoneutral conditions.

The results of the effect of EMMH supplementation on thermal responses, gas exchange and heat production measurements before sun exposure (thermonuteral conditions) are presented in Table (3). The results showed that in Farafra ewes, EMMH supplemented group had significantly $(\mathrm{P}<0.05)$ lower rectal temperature than in control croup (39.33 vs. $39.54{ }^{\circ} \mathrm{C}$ for EMMH and control groups, respectively). However, no significant difference was observed in rectal temperature of Saidi ewes. Skin and wool temperature did not differed between treatments and breeds. Whereas, respiration rate, metabolic rate and heat production were slightly lower (not significant) in EMMH group compared to control group in both breeds. In contrast, gas volume and tidal volume were slightly (not significant) higher in treated group than in control. In addition, no significant differences were found between the two studied breeds and there was no observed interaction between treatment and breed. 
Table (3): Effect of EMMH supplementation on thermal responses, respiratory activities and heat production measurements during thermonuteral conditions.

\begin{tabular}{llcc}
\hline Item & & \multicolumn{2}{c}{ Groups } \\
\cline { 2 - 4 } & Breeds & $\begin{array}{c}\text { Group (I) } \\
\text { Control } \\
(\mathrm{M} \pm \mathrm{SE})\end{array}$ & $\begin{array}{c}\text { Group (II) } \\
\text { EMMH } \\
(\mathrm{M} \pm \mathrm{SE})\end{array}$ \\
\hline Rectal temperature $\left({ }^{\circ} \mathrm{C}\right)$ & Farafra & $39.54^{\mathrm{a}} \pm 0.06$ & $39.33^{\mathrm{b}} \pm 0.08$ \\
Skin temperature $\left({ }^{\circ} \mathrm{C}\right)$ & Saidi & $39.45 \pm 0.06$ & $39.32 \pm 0.04$ \\
& Farafra & $36.16 \pm 0.15$ & $36.07 \pm 0.14$ \\
Wool temperature $\left({ }^{\circ} \mathrm{C}\right)$ & Saidi & $35.92 \pm 0.14$ & $35.81 \pm 0.12$ \\
& Farafra & $35.43 \pm 0.42$ & $35.28 \pm 0.28$ \\
Respiration rate $($ breathe/minute) & Saidi & $35.31 \pm 0.24$ & $35.19 \pm 0.34$ \\
& Farafra & $46.2 \pm 3.3$ & $42.9 \pm 2.1$ \\
Gas volume $(\mathrm{L} /$ minute) & Saidi & $45.1 \pm 2.4$ & $41.2 \pm 2.0$ \\
& Farafra & $6.16 \pm 1.2$ & $6.57 \pm 1.0$ \\
Tidal volume $(\mathrm{ml} /$ breathe) & Saidi & $6.37 \pm 0.9$ & $6.74 \pm 1.3$ \\
& Farafra & $134.4 \pm 10.4$ & $152.1 \pm 8.9$ \\
Metabolic rate & Saidi & $142.2 \pm 11.8$ & $163.2 \pm 12.1$ \\
Heat production & Farafra & $128.2 \pm 11.7$ & $122.3 \pm 15.1$ \\
& Saidi & $129.4 \pm 9.5$ & $124.5 \pm 10.2$ \\
& Farafra & $1.25 \pm 0.06$ & $1.18 \pm 0.05$ \\
& Saidi & $1.21 \pm 0.07$ & $1.14 \pm 0.08$ \\
\hline
\end{tabular}

$a$ and $b$ Means in the same row with different superscripts are significantly different $(P<0.05)$.

Results in table (4) illustrated that rectal temperature significantly $(\mathrm{P}<0.05)$ decreased in EMMH group than in control group in both breeds, for Farafra ewes it was $39.81{ }^{\circ} \mathrm{C}$ vs. 39.52 for control and EMMH groups, respectively and in Saidi ewes it was $39.79^{\circ} \mathrm{C}$ vs. 39.61 for control and EMMH groups, respectively. Similar trend of results was found in skin temperature in addition of a significant $(\mathrm{P}<0.05)$ increase in Saidi compared to Farafra ewes. Respiration rate in Farafra ewes significantly $(\mathrm{P}<0.05)$ decreased in treated group than in the control group (64.1 vs. 73.7 in EMMH and control groups respectively), while it insignificantly decreased in Saidi ewes. Gas volume was insignificantly higher whereas, tidal volume was significantly $(\mathrm{P}<$ $0.05)$ higher in treated group as compared to control in both breeds. However, metabolic rate and heat production values significantly $(\mathrm{P}<0.05)$ decreased in EMMH supplemented group in comparison with the control group without differences between breeds. Generally, EMMH supplementation alleviated the adverse effects of heat stress on thermal responses, respiratory activates, gas exchange measurements and heat production.

Generally, EMMH supplementation alleviated the adverse effects of heat stress on thermal responses, respiratory activates, gas exchange measurements and heat production.

To some extent, the higher values of skin and wool temperature of Saidi ewes than Farafra ones may be explained by the their dark colors (Black or brown) which may absorb more heat as compared to the color of Farafra ewes (White) which reflects the heat.

Several researchers have confirmed that heat stress for short or long periods can impose a variety of physical and psychological stimuli that disrupt homeostasis and metabolism of different animal species (Piccione et al., 2013). Increasing respiration rate, sweating, vasodilation with increased blood flow to skin surface, high rectal temperature, decreased DM intake, efficiency of feed utilization and altered water metabolism are the physiological responses that are associated with negative impacts of heat stress on production and reproduction of animals (West et al., 1999). 
Table (4): Effect of EMMH supplementation on thermal responses, respiratory activities and heat production measurements during heat stress conditions (after solar exposure).

\begin{tabular}{llcc}
\hline Item & & \multicolumn{2}{c}{ Groups } \\
\cline { 2 - 4 } & Breeds & $\begin{array}{c}\text { Group (I) } \\
\text { Control } \\
(\mathbf{M} \pm \mathbf{S E})\end{array}$ & $\begin{array}{c}\text { Group (II) } \\
\text { EMMH } \\
(\mathbf{M} \pm \mathbf{S E})\end{array}$ \\
\hline Rectal temperature $\left({ }^{\circ} \mathrm{C}\right)$ & & $39.81^{\mathrm{a}} \pm 0.07$ & $39.52^{\mathrm{b}} \pm 0.08$ \\
Skin temperature $\left({ }^{\circ} \mathrm{C}\right)$ & Farafra & $39.79^{\mathrm{a}} \pm 0.06$ & $39.61^{\mathrm{b}} \pm 0.05$ \\
& Saidi & $37.39^{\mathrm{Ba}} \pm 0.14$ & $36.72^{\mathrm{Bb}} \pm 0.15$ \\
Wool temperature $\left({ }^{\circ} \mathrm{C}\right)$ & Farafra & $37.82^{\mathrm{Aa}} \pm 0.11$ & $37.12^{\mathrm{Ab}} \pm 0.10$ \\
& Saidi & $38.21 \pm 0.31$ & $38.25 \pm 0.24$ \\
Respiration rate (breathe/minute) & Farafra & $38.83 \pm 0.21$ & $38.67 \pm 0.27$ \\
& Saidi & $73.7^{\mathrm{a}} \pm 3.2$ & $64.1^{\mathrm{b}} \pm 2.7$ \\
Gas volume $(\mathbf{L} /$ minute) & Farafra & $77.2 \pm 3.1$ & $71.4 \pm 3.7$ \\
& Saidi & $7.81 \pm 1.0$ & $8.67 \pm 0.9$ \\
Tidal volume $(\mathbf{m l} / \mathbf{b r e a t h e )}$ & Farafra & $8.12 \pm 0.8$ & $8.49 \pm 1.1$ \\
& Saidi & $106.2^{\mathrm{b}} \pm 5.6$ & $133.2^{\mathrm{a}} \pm 6.2$ \\
Metabolic rate & Farafra & $104.7^{\mathrm{b}} \pm 5.1$ & $121.1^{\mathrm{a}} \pm 4.9$ \\
& Saidi & $263.1^{\mathrm{a}} \pm 11.4$ & $219.5^{\mathrm{b}} \pm 13.7$ \\
Heat production & Farafra & $276.2^{\mathrm{a}} \pm 15.1$ & $233.4^{\mathrm{b}} \pm 12.7$ \\
& Saidi & $1.45^{\mathrm{a}} \pm 0.06$ & $1.22^{\mathrm{b}} \pm 0.08$ \\
& Farafra & $1.52^{\mathrm{a}} \pm 0.05$ & $1.29^{\mathrm{b}} \pm 0.07$ \\
\hline
\end{tabular}

$a$ and $b$ : Means in the same row with different superscripts are significantly different $(P<0.05)$.

$A$ and B: Means in the same column with different capital superscripts are significantly different $(P<0.05)$.

Our results are in agreement with those of Chauhan et al., (2014) who studied antioxidants supplementation in sheep diets during heat stress. They found that physiological responses (rectal, skin and wool temperatures and heat production) were improved during heat stress in supplemented groups. They added that antioxidants supplementation with different doses improved oxidative status and reduce the negative effects of heat stress. Similar results were obtained by Sejian et al., (2014) who reported that dietary antioxidant protected ewes against heat stress in terms of alleviate the effect of heat stress by decreasing rectal temperature, respiration rate and skin temperature. Also, in accordance to our results, animals during heat stress reducing metabolic heat production and improving heat losses by latent and sensible pathways (Renaudeau et al., 2012). These results may be explained by maintaining the antioxidant status of the EMMH supplemented animals from loss during heat stress conditions.

Antioxidants supplementation are free radical scavengers, which protect the body defense system against excessively produced free radicals during heat stress and stabilize health status of the animal (Sánchez et al., 2008). Furthermore, it was reported that probiotics stabilize healthy microbial balance in the intestine which leads to improve animal efficiencies especially in stressed animal which face heat stress or feed on toxic or improper diets (Zinedine et al., 2005).

\section{Body weight changes}

The results in Table (5) presented the effect of EMMH supplementation on average body weight and body weight change of ewes during the experimental period. Average body weight and body weight change significantly $(\mathrm{P}<0.05)$ improved by EMMH supplementation. Whereas, no significant differences were found between breeds. Similar to our results, Sejian et al., (2014) found that antioxidant supplementation increased significantly feed intake and body weight of heat stressed ewes. Also, El-Badawi et al., (2011) investigated the effect of EMMH supplementation in sheep diets and found that body weight gain improved by supplementation of EMMH. Also, they found that EMMH supplementation increased nutrient digestibilities, microbial yield of the rumen and volatile fatty acids content which enhance weight gain. We could explain the improvement of weight gain or change by EMMH supplementation that it contains fungi strains (Trichoderma reesei and Aspergillus oryzae) and yeast (Saccharomyces cervisiae), all of these are the active components 
and can serve as growth promoters for livestock besides it contains natural antioxidants of herbal medicine plants that also had a good effect on growth stimulation, modifying the intestine ecology and improving feed utilization efficiency (Burgain et al., 2011).

Table (5): Effect of EMMH supplementation on body weight change.

\begin{tabular}{llcc}
\hline Item & & \multicolumn{2}{c}{ Groups } \\
\cline { 3 - 4 } & Breeds & Group (I) & Group (II) \\
& & Control & EMMH \\
& & $(\mathrm{M} \pm \mathrm{SE})$ & $(\mathrm{M} \pm \mathrm{SE})$ \\
\hline Average body weight $(\mathrm{kg})$ & Farafra & $40.2^{\mathrm{b}} \pm 1.8$ & $44.6^{\mathrm{a}} \pm 1.1$ \\
& Saidi & $39.4^{\mathrm{b}} \pm 1.5$ & $43.2^{\mathrm{a}} \pm 1.0$ \\
Body weight change $(\mathrm{kg})$ & Farafra & $12.4^{\mathrm{b}} \pm 0.9$ & $15.4^{\mathrm{a}} \pm 0.8$ \\
& Saidi & $11.9^{\mathrm{b}} \pm 0.7$ & $14.5^{\mathrm{a}} \pm 0.9$ \\
\hline
\end{tabular}

$a$ and $b:$ Means in the same row with different superscripts are significantly different $(P<0.05)$.

\section{Reproductive traits}

Data in Table (6) showed the results of the effect of EMMH supplementation on some reproductive traits of ewes. Generally, fertility parameters were improved by treatment in both breeds. Estrus duration was insignificantly higher in treated group than control. Conception rate improved in EMMH group compared to control in both breeds (90.9\% vs. 72.7\% for EMMH and control groups in Farafra ewes) and (81.8 vs. 72.7\% for control and EMMH groups in Saidi ewes). Furthermore, average litter size per ewe, number of lambs born per group, number of twins born per group were improved by EMMH supplementation. Additionally, birth weight of lambs was significantly $(\mathrm{P}<0.05)$ higher in EMMH group than control in both breeds and also within groups, it was significantly $(\mathrm{P}<0.05)$ higher in Farafra lambs than Saidi ones.

Table (6): Effect of EMMH supplementation on reproductive traits.

\begin{tabular}{llcc}
\hline Variable & & \multicolumn{2}{c}{ Groups } \\
\cline { 3 - 4 } & Breeds & $\begin{array}{c}\text { Group (I) } \\
\text { Control }\end{array}$ & $\begin{array}{c}\text { Group (II) } \\
\text { EMMH }\end{array}$ \\
\hline Estrus duration (hrs.) & & $32.5 \pm 1.1$ & $35.3 \pm 1.4$ \\
$(\mathrm{M} \pm \mathrm{SE}$ ) & Farafra & $31.8 \pm 1.2$ & $34.1 \pm 1.1$ \\
Conception rate, (\%) & Saidi & 72.7 & 90.9 \\
& Farafra & 72.7 & 81.8 \\
Avg. gestational period (day), (M \pm SE) & Saidi & $152.3 \pm 1.2$ & $149.4 \pm 1.3$ \\
& Farafra & $152.3 \pm 1.4$ & $150.0 \pm 0.8$ \\
Avg. litter size / ewe & Saidi & 1.25 & 1.30 \\
& Farafra & 1.38 & 1.44 \\
No. of lambs born/ group & Saidi & 10 & 13 \\
& Farafra & 11 & 3 \\
No. of twins born/ group & Saidi & 2 & 3 \\
& Farafra & 3 & $3.31^{\mathrm{Aa}} \pm 0.07$ \\
Birth weight of lambs $(\mathrm{kg}),(\mathrm{M} \pm \mathrm{SE})$ & Saidi & $3.03^{\mathrm{Ab}} \pm 0.08$ & $3.11^{\mathrm{Ba}} \pm 0.05$ \\
\hline
\end{tabular}

$a$ and $b:$ Means in the same row with different small superscripts are significantly different $(P<0.05)$.

$A$ and $B:$ Means in the same column with different capital superscripts are significantly different $(P<0.05)$.

Maternal nutrient restriction caused by heat stress during certain periods of gestation can have significant bad impact on placental and fetal growth and development (Reynolds et al., 2010). Also, free radicals and reactive oxygen species play a number of significant and diverse roles in reproductive biology (Sánchez et al., 
2008). Moreover, lower levels of the antioxidant is associated with poor fertility in ruminants (Nayyar and Jindal, 2010). Similar to our results Chiou et al., (2002) and Zabek et al., (2014) found that using probiotecs with Aspergillus oryzae and Saccharomyces cervisiae improved reproductive performance of cows. These results may be explained by the beneficial effect of EMMH supplementation on heat stress reduction, maintaining acid base balance and antioxidant status and increasing nutrient digestabilities and also feed intake (El Badawi et al., 2011 \& Sejian et al., 2014).

\section{The second trail}

Results in Table (7) illustrated the effect of EMMH supplementation on lactational performance ewes. Total milk yield $(\mathrm{kg})$ during the lactation period significantly $(\mathrm{P}<0.05)$ increased by EMMH supplementation in both breeds. Similarly, average daily milk yield per ewe had the same trend of the significant $(\mathrm{P}<0.05)$ increase in supplemented group in both breeds. There was no significant differences between the two breeds and no interaction between treatment and breed.

Table (7): Effect of EMMH supplementation on milk yield of ewes.

\begin{tabular}{|c|c|c|c|}
\hline \multirow[b]{2}{*}{ Milk yield } & \multirow[b]{2}{*}{ Breeds } & \multicolumn{2}{|c|}{ Groups } \\
\hline & & $\begin{array}{c}\text { Group (I) } \\
\text { Control }\end{array}$ & $\begin{array}{c}\text { Group (II) } \\
\text { EMMH }\end{array}$ \\
\hline \multirow[t]{2}{*}{ Total milk yield / ewe (kg) } & Farafra & $46.7^{\mathrm{b}} \pm 2.0$ & $52.6^{\mathrm{a}} \pm 1.8$ \\
\hline & Saidi & $47.5^{\mathrm{b}} \pm 1.9$ & $54.3^{\mathrm{a}} \pm 2.4$ \\
\hline \multirow[t]{2}{*}{ Avg. daily milk yield / ewe (gm) } & Farafra & $623.6^{\mathrm{b}} \pm 25.4$ & $724.1^{\mathrm{a}} \pm 19.4$ \\
\hline & Saidi & $631.7^{\mathrm{b}} \pm 24.9$ & $726.7^{\mathrm{a}} \pm 25.7$ \\
\hline
\end{tabular}

$a$ and $b:$ Means in the same row with different small superscripts are significantly different $(P<0.05)$.

These results agreed with those of some previous studies in sheep (Moeini et al., 2009 \& Zhao et al., 2008). They reported that antioxidant supplementation significantly increased milk production and in cows (Lacetera et al., 1999).

The negative effect of heat stress on milk production is primarily explained by a reduced nutrient intake and a decrease of nutrient uptake by the portal-drained vein and decreased milk protein content related to a decrease in casein fraction (Bernabucci et al., 2002). It was reported that there are several benefits of probiotics on animal lactational performance included the ability to enhance intestinal health by stimulating the development of a healthy microbiota (predominated by beneficial bacteria), preventing enteric pathogens from colonizing the intestine, increasing digestive capacity, lowering the $\mathrm{pH}$ and improving mucosal immunity (Uyeno et al., 2015).

Results in Table (8) illustrated the effect of EMMH supplementation on some traits of suckling lambs of supplemented ewes. Weaning weight and total gain were significantly $(\mathrm{P}<0.05)$ higher in suckling lambs of EMMH supplemented ewes than in non supplemented ewes in both Farafra and Saidi breeds. Also, within groups, Farafra lambs had significantly $(\mathrm{P}<0.05)$ higher weaning weight and total gain compared to Saidi lambs with significant interaction between treatment and breed. At the same time, this obvious significant difference of total gain did not observed in average daily gain of lambs. Furthermore, it seems interest to note that survival rate was improved in EMMH group than the control group in both breeds. These results agreed with Capper et al., (2005) who reported that antioxidants supplementation of ewes during pregnancy and lactation improved weight gain, survival rate and antioxidant status of suckling lambs by antioxidant supplementation. Similarly, Muñoz et al., (2008) reported that dietary antioxidants improved lamb survival and growth. Our results may be attributed to the higher milk production of supplemented ewes that reflects higher weight gain of their suckling lambs. 
Table (8): Effect of EMMH supplementation on traits of suckling lambs of treated ewes.

\begin{tabular}{llcc}
\hline Item & Breeds & \multicolumn{2}{c}{ Groups } \\
\cline { 3 - 4 } & & Group (I) & Control \\
\cline { 3 - 4 } & Farafra & $14.0^{\mathrm{Ab}} \pm 0.32$ & $\begin{array}{c}\text { Group (II) } \\
\text { EMMH }\end{array}$ \\
\hline Weaning weight (kg) & $13.1^{\mathrm{Bb}} \pm 0.29$ & $15.4^{\mathrm{Aa}} \pm 0.35$ \\
Total gain (kg) & Saidi & $11.05^{\mathrm{Ab}} \pm 0.27$ & $14.3^{\mathrm{Ba}} \pm 0.37$ \\
& Farafra & $10.21^{\mathrm{Bb}} \pm 0.21$ & $12.04^{\mathrm{Aa}} \pm 0.24$ \\
Avg. daily gain (gm) & Saidi & $147.3 \pm 5.7$ & $11.1^{\mathrm{Ba}} \pm 0.28$ \\
& Farafra & $136.1 \pm 5.8$ & $160.5 \pm 6.4$ \\
Survival rate (\%) & Saidi & 80.0 & $148.1 \pm 6.3$ \\
& Farafra & 81.8 & 92.3 \\
& Saidi & 84.6
\end{tabular}

$a$ and $b:$ Means in the same row with different small superscripts are significantly different $(P<0.05)$.

$A$ and B: Means in the same column with different capital superscripts are significantly different $(P<0.05)$.

Results in Table (9) illustrated the effect of EMMH supplementation on some blood hematological and biochemical parameters of ewes (table, 9). Mean values of total protein concentration and total antioxidant capacity (TAC) was significantly ( $\mathrm{P}<0.05)$ higher in EMMH supplemented group in both Farafra and Saidi. However, heamatocrit \%, sodium and potassium concentrations were slightly (not significant) increased by EMMH supplementation. El-Badawi et al., (2011) found similar results as regard the significant increase in TP in EMMH supplemented group. This result may be attributed to the EMMH content of yeast culture and its significant effect in improvement of nitrogen utilization.

It was expected that the total antioxidant capacity increased in EMMH supplemented group as agreed with the results of Chauhan et al., (2014) who supplemented sheep diets with some sources of antioxidant and found that TAC was altered in sheep blood. It was reported that heat stress elevates oxidative stress in ewes as measured by serum total antioxidant capacity and affects animal production (Pregel et al., 2005). Thus, maintaining TAC in EMMH supplemented group certainly had a beneficial effect in heat stress defense and is a good evidence that the animal can cope with these conditions. The slight increase of $\mathrm{Na}$ and $\mathrm{K}$ elements in supplemented group may had an favorable effect in the acid base balance during heat stress which cause an excessive loss of these elements.

Table (9): Effect of EMMH supplementation on some blood hematological and biochemical parameters of ewes.

\begin{tabular}{llcc}
\hline Item & & \multicolumn{2}{c}{ Groups } \\
\cline { 3 - 4 } & Breeds & $\begin{array}{c}\text { Group (I) } \\
\text { Control } \\
(\mathrm{M} \pm \mathrm{SE})\end{array}$ & $\begin{array}{c}\text { Group (II) } \\
\text { EMMH } \\
(\mathrm{M} \pm \mathrm{SE})\end{array}$ \\
\hline Haematocrit (\%) & Farafra & $30.4 \pm 0.7$ & $31.5 \pm 0.5$ \\
& Saidi & $29.7 \pm 0.6$ & $30.4 \pm 0.6$ \\
Total Protein (g/dl) & Farafra & $5.04^{\mathrm{b}} \pm 0.09$ & $5.42^{\mathrm{a}} \pm 0.14$ \\
& Saidi & $4.93^{\mathrm{b}} \pm 0.12$ & $5.32^{\mathrm{a}} \pm 0.08$ \\
Sodium (meq/l) & Farafra & $141.4 \pm 3.4$ & $145.6 \pm 2.9$ \\
& Saidi & $139.1 \pm 2.7$ & $142.5 \pm 2.4$ \\
Potassium (meq/l) & Farafra & $5.05 \pm 0.08$ & $5.21 \pm 0.11$ \\
& Saidi & $4.94 \pm 0.12$ & $5.17 \pm 0.09$ \\
Total Antioxidant capacity (mmol/L) & Farafra & $0.51^{\mathrm{b}} \pm 0.04$ & $0.69^{\mathrm{a}} \pm 0.05$ \\
& Saidi & $0.52^{\mathrm{b}} \pm 0.05$ & $0.66^{\mathrm{a}} \pm 0.04$ \\
\hline
\end{tabular}

$a$ and $b:$ Means in the same row with different small superscripts are significantly different $(P<0.05)$. 


\section{CONCLUSION}

It could be concluded that supplementation of EMMH probiotec, due to its ingredients (useful fungi, yeast, enzymes, and antioxidants) improved physiological responses of sheep during heat stress and consequently can ameliorate the adverse effects of heat stress. In addition, EMMH supplementation improved reproductive performance and lactational performance of ewes and also, improved the performance of their suckling lambs.

\section{REFERENCES}

Abd El-Moneim, M. R. A., M. R. Ramy, I. M. Shaimaa and M. H. Mona. (2012). Antioxidant activity and biological evaluations of probiotic bacteria strains. Int. J. of Acad. Res. Part A; 4 (6), 131-139.

Ashmawy, B. M. (1980). Comparison of three techniques for the estimation of the milk production of small ruminants. Egyptian J. Anim. Prod., 20:11.

Bernabucci, U., B. Ronchi, N. Lacetera, A. Nardone (2002). Markers of oxidative status in plasma and erythrocytes of transition dairy cows during the hot season. J. Dairy Sci. 85:2173-2179.

Burgain, J., C. Galani, M. Linder and J. Scher (2011). Encapsulation of probiotic living cells: From laboratory scale to industrial applications. J. Food Eng., 104: 467-483.

Capper, J. L., G. Robert, K. Eleni, E. P. Sandra, M. M. Alexander and L. A. Sinclair. (5005). The effect of dietary vitamin $\mathrm{E}$ and fatty acid supplementation of pregnant and lactating ewes on placental and mammary transfer of vitamin E to the lamb. Br. J. Nutr. 93 (4), 549-557. 4.

Chauhan, S. S., P. Celi , B. J. Leury, I. J. Clarke and F. R. Dunshea. (2014). Dietary antioxidants at supranutritional doses improve oxidative status and reduce the negative effects of heat stress in sheep. $\mathbf{J}$ Anim Sci.; 92(8):3364-74.

Chiou P., W., C. Chao-Ren and Y. Bi (2002). Effects of Aspergillus oryzae fermentation extract on performance of lactating cows in the summer and winter in Taiwan. Asian-Aust. J. Anim. Sci. Vol. 15, No. 3: 382-389.

de Baets, L., P. Iwaarden, N. Meeus, H. Schimmel, W. Philipp and H. Emons (2009). First certified reference materials for molecular finger priming of two approved probiotic Bacillus strains. Int J Food Microbiol, 129 (1):16-20.

EI-Badawi, A.Y. and A. A. Abedo (2009). Effect of feeding a new bio feed additive with medicinal herbs (EMMH) on growth performance of Barki sheep. Egyptian J. of Nutr. and Feeds, 12 Issue) 3: 335.

El-Badawi, A.Y., F. F. Abou Ammou, A. A. Mahrous, M.H. E1-Shafie, T.M.M. Abdel-Khalek and Y. H. Hafez (2011). Nutritional evaluation of a fungal-yeast probiotic fortified with natural antioxidants on performance of sheep. 1-Nutrients digestibilities, dietary nitrogen utilization, rumen fermentation and chances of blood biochemical constituents. Egypt. J. Nutr. and Feeds, 14 (3):367-377.

El-Shaer, E. K. H. I. (2003). Nutritional studies in ruminants. "Effect of yeast culture supplementation and concentrate: roughage ratio on performance of growing lambs." Ph. D. Thesis, Fac. Agric., Mansoura Univ.

Hahn, G. L., T. L. Mader and R. A. Eigenberg (2003). Perspective on development of thermal indices for animals studies and management. Proceeding of the interaction between climate and animal production symposium, Viterbo., Italy, September, 2003, EAAP Technical Series 7: 31-44.

Lacetera, N., U. Bernabucci, B. Ronchi and A. Nardone (1999). The effects of injectable sodium selenite on immune function and milk production in Sardinian sheep receiving adequate dietary selenium. Vet. Res. 30: 363-370. 
Moeini, M. M., H. Karami and E. Mikaeili (2009). Effect of selenium and vitamin E supplementation during the late pregnancy on reproductive indices and milk production in heifers. Anim. Reprod. Sci. 114: 109114.

Muñoz, C., A. F. Carson, M. A. McCoy, L. E. R. Dawson, D. Irwin, A. W. Gordon, and D. J. Kilpatrick. (2009). Effect of supplementation with barium selenate on the fertility, prolificacy and lambing performance of hill sheep. Vet. Rec. 164:265-272.

Nayyar, S. and R. Jindal (2010): Essentiality of antioxidant vitamins for ruminants in relation to stress and reproduction. Iranian J. of Vet. Res. 11, 1-9.

Piccione, G., S. Casella, C. Giannetto, M. Bazzano, E. Giudice and F. Fazio (2013). Oxidative stress associated with road transportation in ewes. Small Rumin. Res. 112:235-238

Pregel P, E. Bollo, F. T. Cannizzo, B. Biolatti, E. Contato and P. G. Biolatti (2005). Antioxidant capacity as a reliable marker of stress in dairy calves transported by road. Vet. Rec. 162:53-54

Renaudeau, D., A. Collin, S. Yahav, V. de Basilio, J.L. Gourdine and R.J. Collier (2012). Adaptation to hot climate and strategies to alleviate heat stress in livestock production. Animal 6:707-728

Reynolds, L. P., P. P. Borowicz, J. S. Caton, K. A. Vonnahme, J. S. Luther, D. S. Buchanan, S. A. Hafez, A. T. Grazul-Bilska, and D. A. Redmer. (2010). Utero-placental vascular development and placental function: An update. Int. J. Dev. Biol. 54:355-366.

Sánchez, J., A. Jiménez, S. Regodón and S. Andrés. (2008). Inhibitory effect of selenium supplementation on the reproductive performance in synchronized Merino sheep at range conditions in a selenium-defi cient area. Reprod. Domest. Anim. 43:328-332.

Sejian, V., A. K. Singh, A. Sahoo and S. M. K. Naqvi. (2014). Effect of mineral mixture and antioxidant supplementation on growth, reproductive performance and adaptive capability of Malpura ewes subjected to heat stress. J. of Anim. Physiol. and Anim. Nutr. 98 72-83

Sivakumar, A. V. N., G. Singh and V. P. Varshney (2010). Antioxidants supplementation on acid base balance during heat stress in goats. Asian-Aust. J. Anim. Sci. Vol. 23, No. 11 : $1462-1468$

SPSS (2010). Inc. Headquarters, 233 S. Wacker Drive, Statistical analysis system (version 11) Chicago, Illinois 60606.

Spyropoulos, B. G., P. Evangelos, M. Misiakos, and N. Christos (2011). Antioxidant properties of probiotics and their protective effects in the pathogenesis of radiation-induced enteritis and colitis. Dig. Dis. Sci. $56: 285-294$.

Uyeno, Y., S. Suguru and S. Takeshi (2015). Effect of probiotics/prebiotics on cattle health and productivity. Microbes Environ. Vol. 30, No. 2, 126-132

Veizaj-Delia, E., T. Piu, P. Lekaj and M. Tafaj (2010). Using combined probiotic to improve growth performance of weaned piglets on extensive farm conditions. Livest. Sci., 134: 249-251.

West, J. W., G. M. Hill, J. M. Fernandez, P. Mandebvu and B. G. Mullinix (1999). Effects of dietary fiber on intake, milk yield, and digestion by lactating dairy cows during cool or hot, humid weather. J. Dairy Sci. 82: 2455-2465.

Wolter, R. (1995). Dietetic feeds and nutritional supplements. In: Biotechnology in the Feed Industry. proceedings of Alltech's Eleventh Annual Symposium, pp. 143, (Ed.) TP Lyons and KA lacques UK.

Zabek, K., M. Stanisław, W. Roman and K. Andrzej (2014). The effects of supplementing diets fed to pregnant and lactating ewes with Saccharomyces cerevisiae dried yeast. Turk. J. Vet. Anim. Sci. 38: 2002062

Zhao, L., D. Liu, P. Yang, P. Chen and W. Y. Dong (2008) Supplementation with Selenium and Vitamin E Improves Milk Fat Depression and Fatty Acid Composition in Dairy Cows Fed Fat Diet. Asian-Aust J Anim Sci 21: 838-844.

Zinedine, A., M. Faid and M. Benlemlith (2005). In Vitro Reduction of Aflatoxin B1 by Strains of Lactic Acid Bacteria Isolated from Sourdough Bread. Int. J. of Agric.and Biol., 7, 67-70. 
القأثير التظذية على معزز حيوي مدعم بمضادات الأكسدة الطبيعية على الاستجابات الفسيولوجية و إنتاج اللبن للأغنام

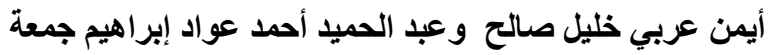 \\ قسم بحوث الأغنام والداغز، معطل بحوث الإنتاج الحيواني ، الدقى ، جيزه، مصر.
}

أستُخدم في هذه الدراسة عدد ثمانية وثمانون نعجة في تجربتين مختلفتين (أربعة وأربعون نعجة لكل تجربة) و هدفت هذه الدراسة لتقييم تأثير التغذية على معزز حيوي يحتوى على فطرى

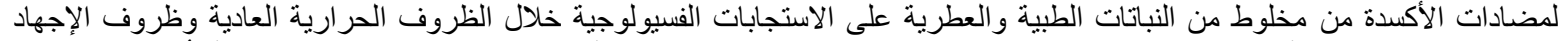

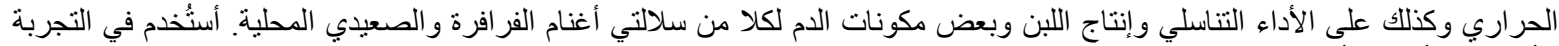

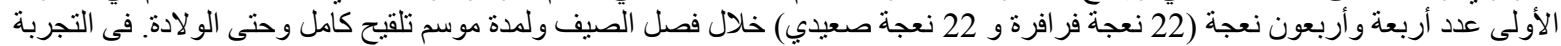

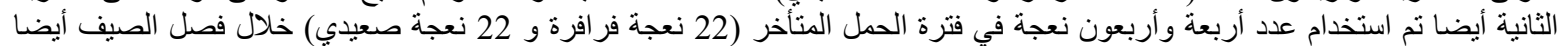

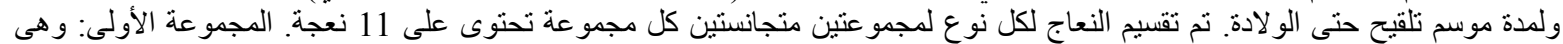

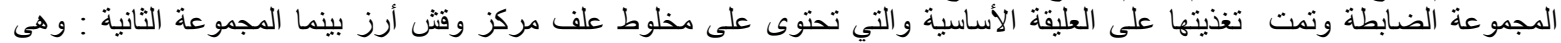

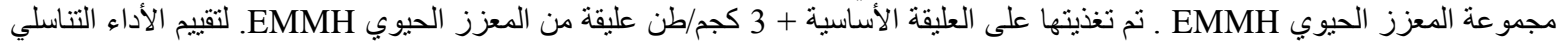

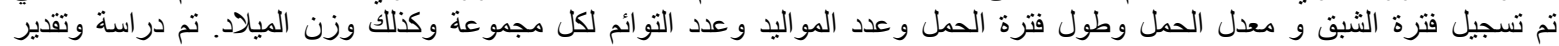

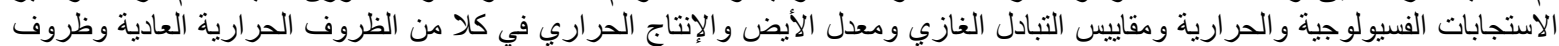

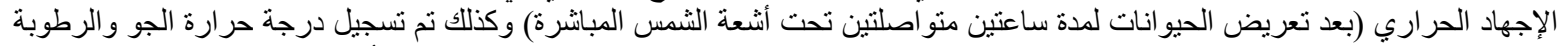

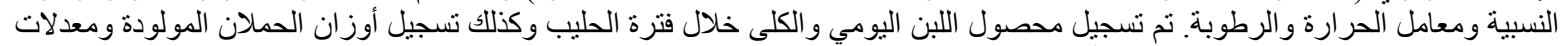

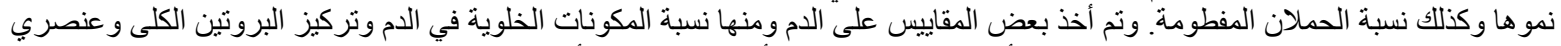

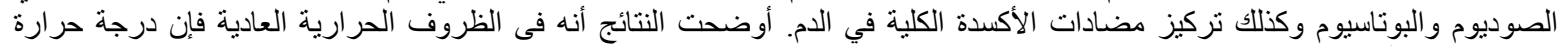

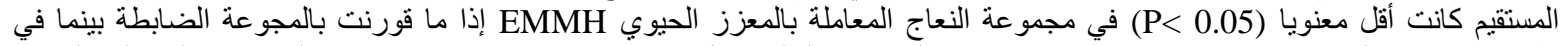

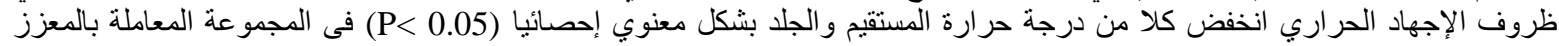

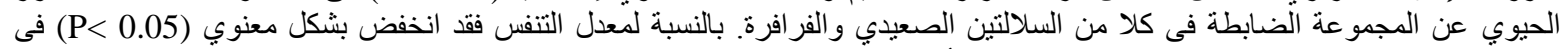
مجموعة الـ EMMH للنعاج الفرافرة فقط وقد ووجد الن الن حجم التنفسة TV ارتفع بشكل معنوي (P)

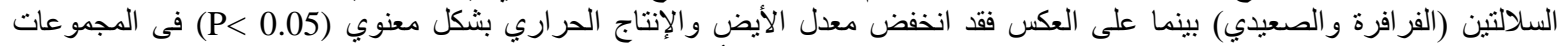

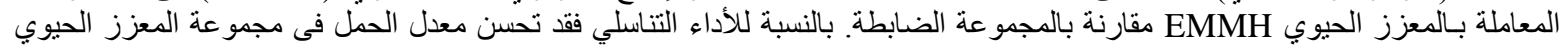

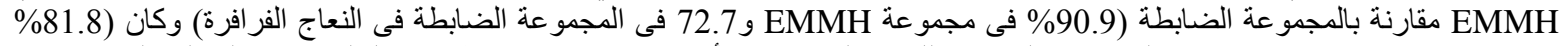

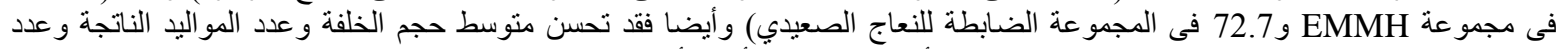

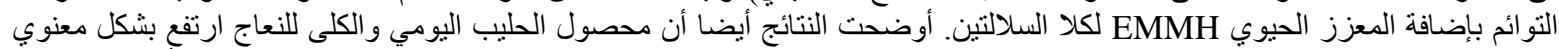

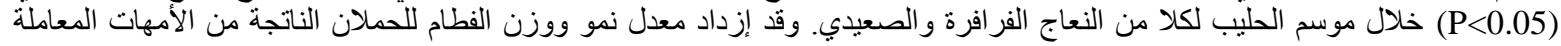

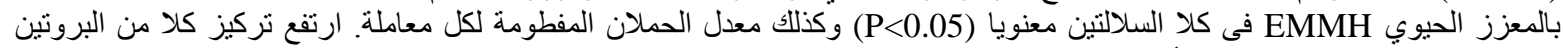

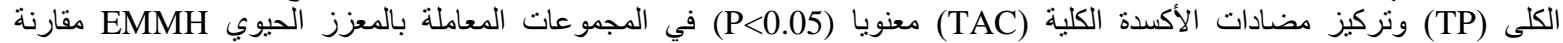

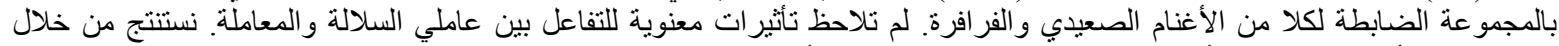

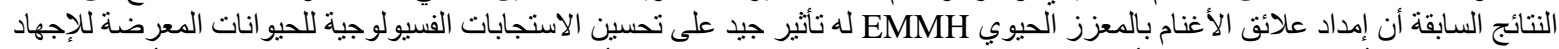

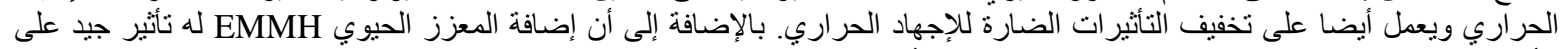

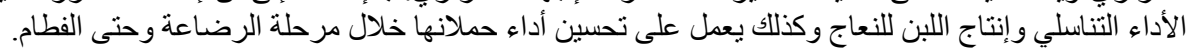

